\title{
Alternative Energetics DC Microgrid With Hydrogen Energy Storage System
}

\author{
Genadijs Zaleskis (Researcher, Riga Technical University), \\ Ingars Steiks (Leading Researcher, Riga Technical University)
}

\begin{abstract}
This paper is related to an alternative energetics microgrid with a wind generator and a hydrogen energy storage system. The main aim of this research is the development of solutions for effective use of the wind generators in alternative energetics devices, at the same time providing uninterrupted power supply of the critical loads. In this research, it was accepted that the alternative energetics microgrid operates in an autonomous mode and the connection to the conventional power grid is not used. In the case when wind speed is low, the necessary power is provided by the energy storage system, which includes a fuel cell and a tank with stored hydrogen. The theoretical analysis of the storage system operation is made. The possible usage time of the stored hydrogen depends on the available amount of hydrogen and the consumption of the hydrogen by the fuel cell. The consumption, in turn, depends on used fuel cell power. The experimental results suggest that if the wind generator can provide only a part of the needed power, the abiding power can be provided by the fuel cell. In this case, a load filter is necessary to decrease the fuel cell current pulsations.
\end{abstract}

Keywords - DC-DC power converters; Energy resources; Energy storage; Fuel cells; Renewable energy sources; Uninterruptable power systems; Wind energy.

\section{INTRODUCTION}

In [1], [2], the strategic objectives of the renewable energy resources (RES) use were established:

- decrease in the use of fossil fuel;

- decrease in the costs of fuel import;

- decrease in the energetics complex environmental pressure;

- provision of the energy of the decentralized consumers and regions with a remote or seasonal delivery of fuel.

For the realization of the functions of renewable sources integration and the power supply of decentralized consumers, the alternative energetics microgrids [3] are used. Such microgrids by the definition can operate synchronously with the conventional power grid or in autonomous mode, according to technical and economical requirements [4]-[7].

The main aim of this research is to develop the solutions for effective use of the renewable energy resources (wind generators in particular) in alternative energetics devices, at the same time providing uninterrupted power supply of the critical loads. It was accepted that the researched alternative energetics microgrid operates in an autonomous mode, and the connection to the conventional power grid is not used. In this case, an uninterrupted power supply can be provided by using the energy storage system (ESS). The ESS based on hydrogen was chosen in this work. The experiments were planned at a reduced scale, and the reference for the DC bus was $40 \mathrm{~V}$, which was necessary for the safety of the work and for the establishment of the main principles of the system.

\section{DC MICROGRID WITH RENEWABLE ENERGY SOURCES}

\section{A. Configuration of the DC Microgrid}

According to [8]-[12], there are three basic configurations of microgrids: DC coupling, AC coupling, and DC and AC coupling. The advantages of DC coupling [9], [13]-[19], compared to AC coupling, are RES integration with smaller conversion losses, uninterruptible power supply by using ESS, simpler control, etc.

In the DC microgrid (Fig. 1), generating components (power grid or RES), loads, and ESS are connected to the DC bus through the AC-DC or DC-DC converters. Depending on the power grid operator rules, the energy generated by RES can be transferred to the power grid [20]-[22].

\section{B. Wind Generator as the Basic Energy Source}

In the case of DC grid, it is reasonable to use the wind generator that includes a synchronous generator with permanent magnets [23]. Thus, the converter, which will provide full power electronic conversion, is necessary (Fig. 2). For the experiments, the buck-boost converter [24] was chosen, as at the rated generator speed the output DC voltage already exceeds the DC bus voltage.

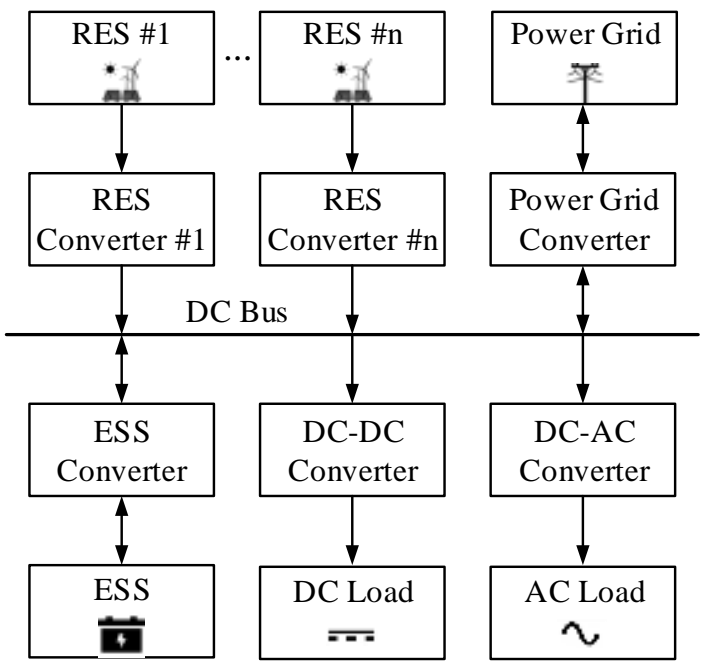

Fig. 1. Configuration of the alternative energetics DC microgrid.

The chosen topology (Fig. 3) can operate in voltage stepdown and step-up modes that are required for the power 
supply system with a $600 \mathrm{~V}$ DC-bus voltage level. The previous experiments showed that this type of the converter ensures high efficiency at the rated power [25]-[27]. In stepdown (buck) mode, this scheme matches the classic buck converter (elements C1, Q1, D1, L1, and C2) with the series diode D2 on the output. The transistor Q2 is constantly off, and Q1 is working in PWM mode. In step-up (boost) mode, the circuit operation is similar to that of the boost converter with the parallel-connected diode D1 on the input. The transistor Q1 is constantly in conduction mode, and Q2 is working in PWM.

\section{HYDROGEN-BASED ENERGY STORAGE SYSTEM}

The hydrogen energy storage system [28], [29] includes three main components (Fig. 4):

- electrolyser - used to break down water into hydrogen and oxygen;

- tank - used for storing the compressed hydrogen;

- fuel cell - used for the conversion of the stored chemical energy (hydrogen) into electrical energy.

The electrolyser and the fuel cell are connected to the DC bus through the corresponding converters, but the electrolyser can be excluded from the system; in latter case, the tank is used as a limited hydrogen source. The pressure regulator is used for ensuring the necessary hydrogen pressure for the fuel cell.

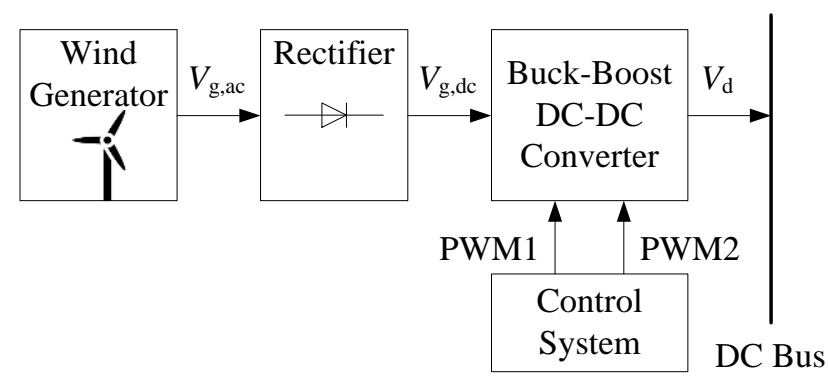

Fig. 2. Connection of the wind generator to the DC bus: $V_{\mathrm{g}, \mathrm{ac}}-$ wind generator output AC voltage; $V_{\mathrm{g}, \mathrm{dc}}-$ wind generator rectified voltage; $V_{\mathrm{d}}-\mathrm{DC}$ bus voltage; PWM1 - control signal for the buck mode; PWM2 - control signal for the boost mode.

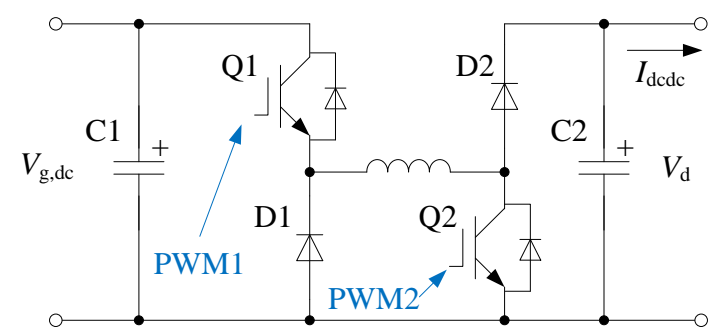

Fig. 3. Buck-boost DC-DC converter: C1, C2 - input and output filters; Q1, Q2 - power switches; D1, D2 - power diodes; L1 - inductor; $V_{\mathrm{g}, \mathrm{dc}}-$ wind generator rectified voltage; $V_{\mathrm{d}}-\mathrm{DC}$ bus voltage; $I_{\mathrm{dcdc}}-$ current from the DCDC converter.
The main parameters of the fuel cell used in the microgrid are given in Table 1. The operation pressure is in the range from $515 \mathrm{kPa}$ to $690 \mathrm{kPa}$, and the output of the pressure regulator is:

$$
p_{\mathrm{H} 2 \text {,p.r. }}=\left\{\begin{array}{l}
p_{\mathrm{H} 2, \max }, p_{\mathrm{H} 2} \geq p_{\mathrm{H} 2, \max }(\mathrm{Pa}), \\
p_{\mathrm{H} 2}, p_{\mathrm{H} 2}<p_{\mathrm{H} 2, \text { max }}
\end{array}\right.
$$

where $p_{\mathrm{H} 2}-$ hydrogen pressure in the tank, $\mathrm{Pa}$;

$p_{\mathrm{H} 2, \max }-$ maximum fuel cell operation pressure, $\mathrm{Pa}$.

TABLE I

Fuel Cell PARAmeters

\begin{tabular}{|l|l|}
\hline \multicolumn{1}{|c|}{ Parameter } & \multicolumn{1}{c|}{ Value } \\
\hline Rated power & $8.5 \mathrm{~kW}$ \\
\hline Operation voltage & $27-36 \mathrm{~V}$ \\
\hline Operation current & $0-350 \mathrm{~A}$ \\
\hline Hydrogen consumption & $\leq 1301 / \mathrm{min}$ \\
\hline Operation pressure & $515-690 \mathrm{kPa}$ \\
\hline
\end{tabular}

Respectively, there is a certain amount of hydrogen $n_{\mathrm{H} 2 \text {,min }}$ at which pressure becomes less than the fuel cell working pressure. So, the available amount of hydrogen is equal to:

$$
n_{\mathrm{H} 2, \mathrm{av}}=n_{\mathrm{H} 2 \text {,rated }}-n_{\mathrm{H} 2 \text {, min }}(\mathrm{mol}) \text {, }
$$

where $n_{\mathrm{H} 2 \text {,rated }}$ - the amount of hydrogen stored in the tank.

\section{OPERATION PRINCIPLE AND ANALYSIS OF THE HYDROGEN ENERGY STORAGE SYSTEM IN THE DC MICROGRID}

\section{A. Operation Principle of the Hydrogen Energy Storage in the DC Microgrid}

The operation principle of the hydrogen ESS was described in [30]. The output voltage of the wind generator DC-DC converter is stabilized to a constant voltage $V_{\mathrm{d}, \mathrm{r}}$, which is the rated voltage of the DC bus (Fig. 5).

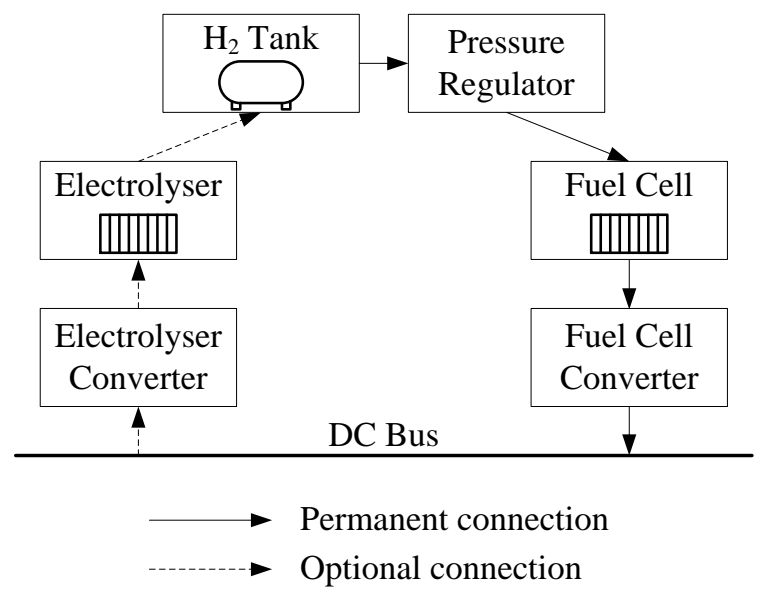

Fig. 4. Block diagram of the hydrogen energy storage system. 
In the case of overload or wind speed decreasing, the output voltage of the DC-DC converter starts to decrease too. The fuel cell output is stabilized to a lower voltage level $\left(V_{\mathrm{d}, \mathrm{r}}-\right.$ $\Delta V$ ). Both power sources are connected to DC bus through diodes [30], because of the diode included in fuel cell module; therefore, the bigger voltage (wind) provides the power in the intervals 1 and 2 (Fig. 5) and both power sources are providing power in the interval 3. These intervals are continuously changing in accordance with the speed of the wind [30].

The load current in the interval 3 is equal to:

$$
I_{\text {load }}=I_{\text {dcdc }}+I_{\text {f.c. }}(\mathrm{A}) \text {, }
$$

where $I_{\text {load }}$ - load current, A;

$I_{\mathrm{dcdc}}-\mathrm{DC}-\mathrm{DC}$ converter current, A;

$I_{\text {f.c. }}-$ fuel cell current, A.

\section{B. Analysis of the Hydrogen Energy Storage Operation}

The rated amount of hydrogen in the tank is:

$$
n_{\mathrm{H} 2 \text {, rated }}=\frac{p_{\mathrm{H} 2} \cdot V_{\mathrm{t}}}{R \cdot T}(\mathrm{~mol}),
$$

where $p_{\mathrm{H} 2}-$ hydrogen pressure in the tank, $\mathrm{Pa}$;

$V_{\mathrm{t}}-$ tank volume, $\mathrm{m}^{3}$;

$R=8.31 \mathrm{~J} /(\mathrm{mol} \cdot \mathrm{K})-$ gas constant;

$T$ - absolute temperature, $\mathrm{K}$.

The dependency of the hydrogen amount in the tank on the tank volume and gas pressure is presented in Fig. 6. For the tank used in the experiments, the rated amount of hydrogen at the initial pressure $20 \mathrm{MPa}$ is equal to $403 \mathrm{~mol}$. According to Table I, the consumption of the hydrogen by the fuel cell is equal to:

$$
V_{\mathrm{H} 2}^{\prime}=\frac{V_{\mathrm{H} 2, \text { rated }}^{\prime}}{P_{\text {f.c.,rated }}} \cdot P_{\text {f.c. }}[1 / \mathrm{min}],
$$

where $V_{\mathrm{H} 2}^{\prime}$ - hydrogen consumption by the fuel cell at atmospheric pressure, $1 / \mathrm{min}$;

$V^{\prime}{ }^{\prime}$, rated - hydrogen consumption by the fuel cell at the rated power and atmospheric pressure, $1 / \mathrm{min}$;

$P_{\text {f.c., rated }}-$ rated power of the fuel cell, W;

$P_{\text {f.c. }}-$ used power of the fuel cell, W.

For the mentioned fuel cell, hydrogen consumption is:

$$
V_{\text {H2 }}^{\prime}=\frac{130}{8500} \cdot P_{\text {f.c. }}=0.0153 \cdot P_{\text {f.c. }}(1 / \mathrm{min}) \text {. }
$$

The consumption of hydrogen in $\mathrm{mol} / \mathrm{s}$ is:

$$
n_{\mathrm{H} 2}^{\prime}=\frac{p_{\mathrm{atm}} \cdot V_{\mathrm{H} 2}^{\prime}}{R \cdot T \cdot 60 \cdot 1000}(\mathrm{~mol} / \mathrm{s}),
$$

where $p_{\text {atm }}-$ atmospheric pressure, $\mathrm{Pa}$.

For the mentioned fuel cell, the consumption of hydrogen is $1.03 \cdot 10^{-5} \cdot P_{\text {f.c. }} \mathrm{mol} / \mathrm{s}$. The possible usage time of the stored hydrogen amount is:

$$
t=\frac{n_{\mathrm{H} 2 \mathrm{av}}}{n_{\mathrm{H} 2}^{\prime}}=\frac{n_{\mathrm{H} 2, \text { rated }}-n_{\mathrm{H} 2, \mathrm{~min}}}{n_{\mathrm{H} 2}^{\prime}}(\mathrm{s}),
$$

where $n_{H 2}$, min should be calculated according to the fuel cell operation pressure and tank volume:

$$
n_{\mathrm{H} 2, \min }=\frac{p_{\mathrm{H} 2, \min } \cdot V_{\mathrm{t}}}{R \cdot T}(\mathrm{~mol}),
$$

where $p_{\mathrm{H} 2, \text { min }}-$ minimum fuel cell operation pressure, $\mathrm{Pa}$.

For the mentioned fuel cell and tank at $p_{\mathrm{H} 2 \text {, min }}=515 \mathrm{kPa}$ and $V_{\mathrm{t}}=0.05 \mathrm{~m}^{3}$, the unused amount of hydrogen $n_{\mathrm{H} 2 \text {,min }}$ is 11 mols, i.e., $2.73 \%$ of the rated amount. The electrolyser was not applied in this work. The possible usage time of the stored hydrogen depends on the available amount of hydrogen and the consumption of the hydrogen by the fuel cell, which is the function from the used fuel cell power, as it is presented in Fig. 7.

\section{EXPERIMENTAL RESULTS}

In the experiment, the wind generator was replaced with a DC power source (Fig. 8). The fuel cell was connected to the DC bus only through the diode without the step-up converter; therefore, the $40 \mathrm{~V}$ rated DC bus voltage was accepted. The experimental results (Fig. 9) confirm the theoretical method (Fig. 5) described in [30].

When the output voltage of the DC-DC converter is less than the voltage of the fuel cell, the DC bus voltage $V_{\mathrm{d}}$ (Fig. 9.b) is equal to fuel cell voltage and the load current $I_{\text {load }}$ is equal to fuel cell current $I_{\text {f.c. }}$. The increase in the DC-DC converter output voltage was made by increasing the duty ratio of the power switch Q2 (Fig. 3). The duty ratio of the switch Q1 is $100 \%$, because of the $30 \mathrm{~V} \mathrm{DC}$ input voltage and stepup operation mode chosen for the experiment. Increasing the DC-DC converter output voltage, the current $I_{\mathrm{dcdc}}$ and DC bus voltage $V_{\mathrm{d}}$ increases till $V_{\mathrm{d}}$ reaches the rated value.

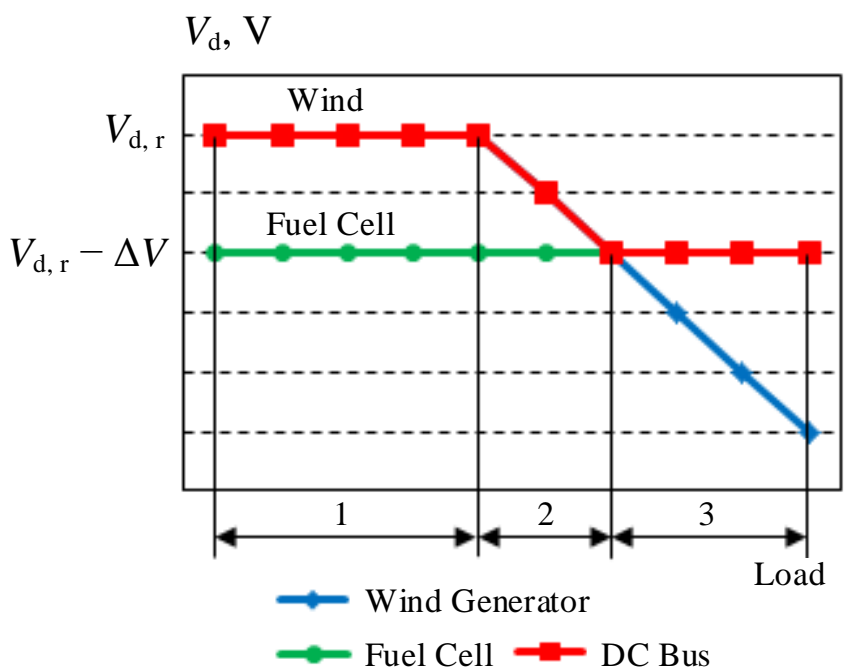

Fig. 5. The voltage/load characteristics of the alternative energetics microgrid: $\mathrm{V}_{\mathrm{d}}-\mathrm{DC}$ bus voltage; $V_{\mathrm{d}, \mathrm{r}}-\mathrm{DC}$ bus rated voltage. 
The form of the current is very important for the fuel cell. When the load is powered only by the fuel cell, the form of current is smooth (Fig. 10). In the case when the load is powered partially by DC-DC converter and partially by the fuel cell, a filter is required. The diagrams of the current without a filter are presented in Figs 11-12.

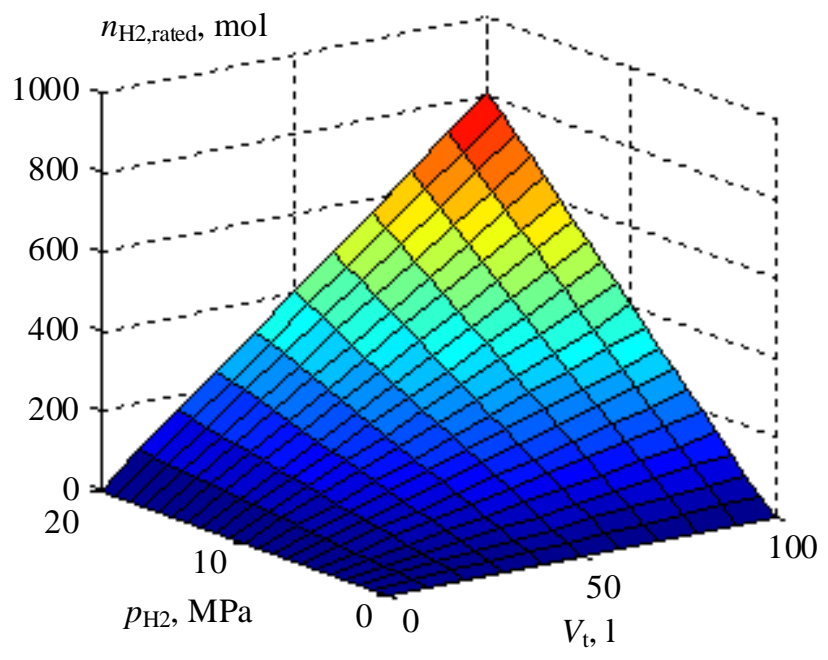

Fig. 6. Amount of hydrogen in a tank depending on the volume of the tank and the pressure of hydrogen.

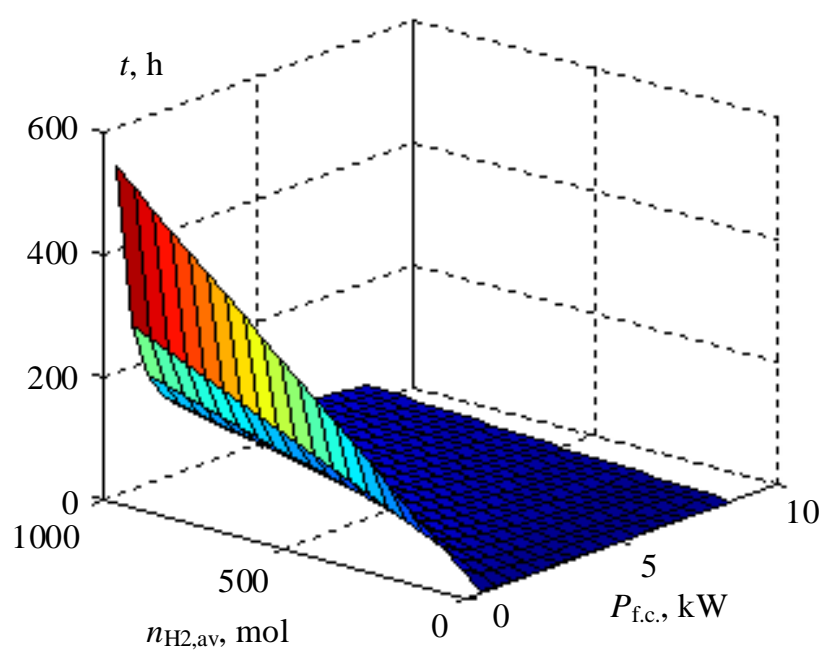

Fig. 7. Possible usage time in hours of the stored hydrogen depending on the used power of the fuel cell and the available hydrogen amount.

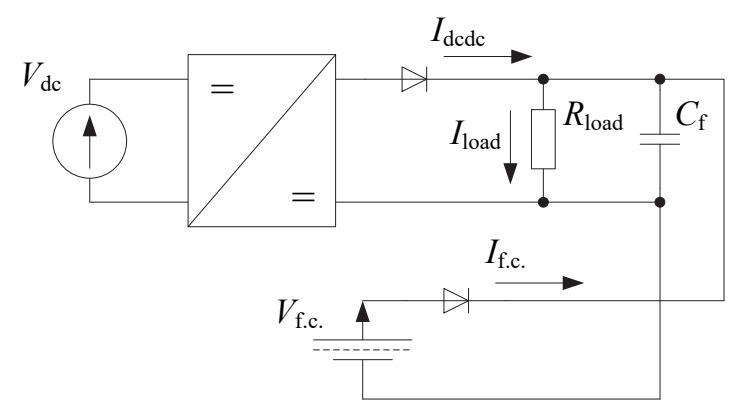

Fig. 8. The simplified principal scheme of the experiment.
The experiments demonstrated that the pulsations of the current are caused by the DC-DC converter that operates in PWM mode. The pulsations increase in this case by decreasing the current of the fuel cell. The usage of the $450 \mu \mathrm{F}$ capacitor can improve the form of the current at the $39 \Omega$ load (Figs 13-14). The capacity of the filter was selected experimentally, and its calculation is the aim of our future work.

\section{CONCLUSION}

According to the strategic objectives of the use of renewable energy resources, the alternative energetics microgrid based on the wind energy was used in this research with the aim to develop the solutions for effective use of the renewable energy resources (wind generators in particular) in alternative energetics devices, at the same time providing an uninterrupted power supply of the critical loads.

After the analysis of the possible configurations of the microgrid, the DC coupling was chosen, because there are advantages corresponding to renewable energy sources and energy storage systems. The autonomous operation mode of the microgrid was chosen, which means that the conventional power grid is not applied, and in the case of low wind power, the energy storage system is necessary for providing an uninterrupted power supply. The experimental results demonstrate that the hydrogen energy storage system provides an uninterrupted power supply in the alternative energetics microgrid based on wind energy. In the case when the wind generator speed is low, the necessary power is provided by the fuel cell.

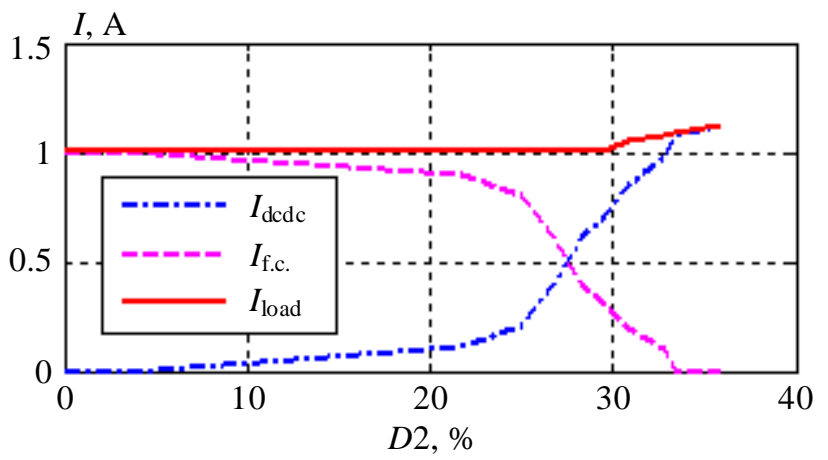

a

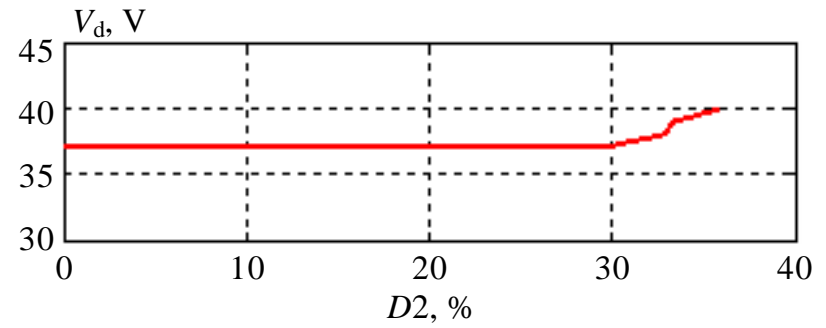

$\mathrm{b}$

Fig. 9. Currents (a) and DC bus voltage (b) depending on the DC-DC converter duty ratio $D 2$ in the boost mode at the $30 \mathrm{~V}$ DC converter's input voltage. 
If the wind speed and, the wind generator output power is sufficient, the fuel cell must be in the "run" mode all the time, because the transition from stand-by mode to run (power ready) mode can require up to 5 seconds [31], [32].

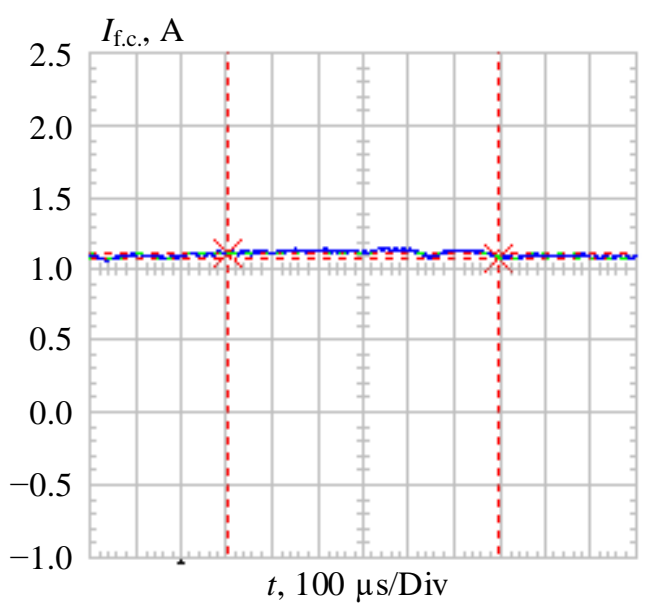

Fig. 10. Current of the fuel cell in the case when load is powered only by the fuel cell.

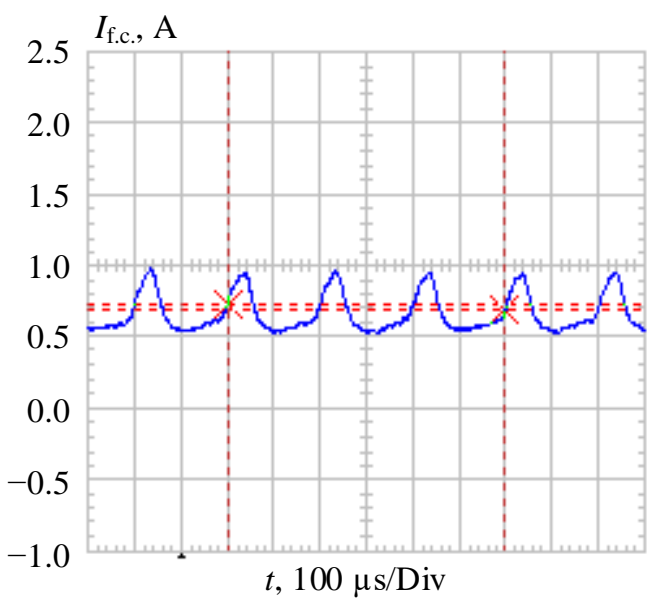

Fig. 11. Current of the fuel cell with rms $0.66 \mathrm{~A}$ in the case when load is partially powered by the fuel cell without a load filter.

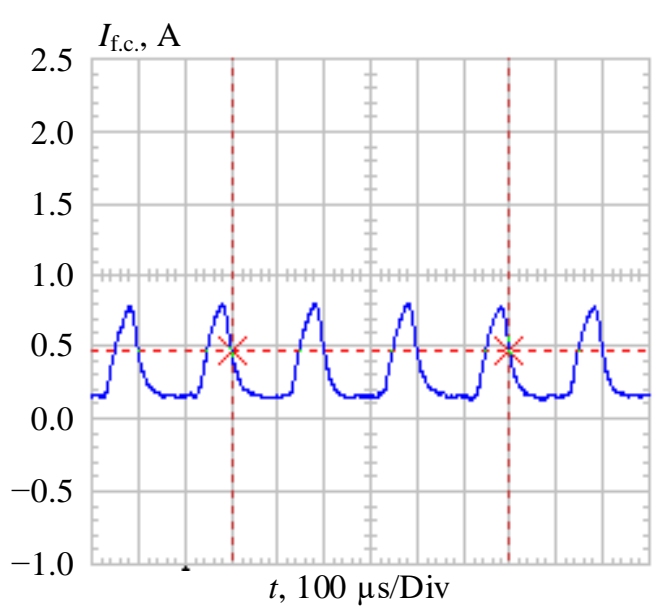

Fig. 12. Current of the fuel cell with rms $0.32 \mathrm{~A}$ in the case when load is partially powered by the fuel cell without a load filter.
Theoretical analysis of the microgrid operation with the hydrogen energy storage system includes the calculation of the hydrogen consumption and the possible usage time of the stored hydrogen in the case when the tank is applied instead of the electrolyser. The possible usage time of the stored hydrogen depends on the available amount of hydrogen and the consumption of hydrogen by the fuel cell, which is the function from the used fuel cell power.

The hydrogen consumption was calculated for the full-scale system, but the precision of the hydrogen pressure measurement device was not enough for a small-scale experiment at small duration and power; therefore, there is no experimental data about hydrogen consumption.

The experimental results demonstrated that if the wind generator can provide only a part of the needed power, the abiding power can be provided by the fuel cell. In this case, a load filter is necessary to decrease the fuel cell current pulsations. When the output voltage of the DC-DC converter is less than the fuel cell voltage, the DC bus voltage is equal to the fuel cell voltage and the load current is equal to the fuel cell current.

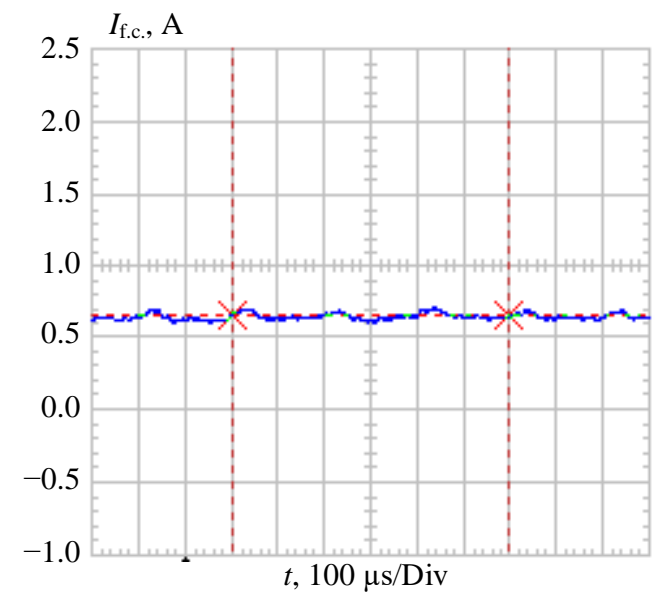

Fig. 13. Current of the fuel cell with rms $0.65 \mathrm{~A}$ in the case when load is partially powered by the fuel cell with a load filter.

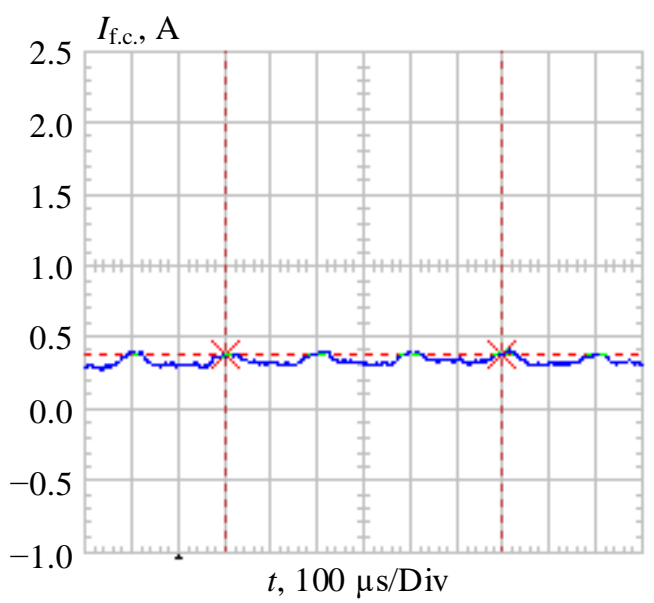

Fig. 14. Current of the fuel cell with rms $0.32 \mathrm{~A}$ in the case when load is partially powered by the fuel cell with a load filter. 
Increasing the DC-DC converter output voltage, the converter's current and DC bus voltage increases till DC bus voltage reaches the rated value. When the load is powered only by the fuel cell, the form of the current is smooth. In the case when the load is powered partially by DC-DC converter and partially by the fuel cell, a filter is required to prevent undesirable pulsations.

\section{ACKNOWLEDGMENT}

This work has been supported by the Latvian National Research program LATENERGI.

\section{REFERENCES}

[1] Latvijas Republikas Vides aizsardzības un reǵionālās attīstības Ministrija, "Atjaunojamo energoresursu izmantošanas pamatnostādnes 2006.-2013. gadam (informativa dala)," Rīga, 2006.

[2] A. Adamovičs, V. Dubrovskis, I. Plūme, Ā. Jansons, D. Lazdina and A. Lazdiňš, Biomasas izmantošanas ilgstspējības kritêriju pielietošana un pasākuтu izstrāde, Rīga, 2009.

[3] K. Bunker, S. Doig, K. Hawley, and J. Morris, "Renewable Microgrids: Profiles From Islands and Remote Communities Across the Globe," 2015

[4] The Microgrids Group at Berkeley Lab, "About Microgrids." [Online]. Available: https://building-microgrid.lbl.gov/about-microgrids-0.

[5] H. S. Kumar, "Smart microgrid." 2015.

[6] The Microgrids Group at Berkeley Lab, "Microgrid Definitions." [Online].

Available: https://building-microgrid.lbl.gov/about-microgrids-0.

[7] T. Roughan, "Workshop on Microgrid Technologies and Applications," RPI Cent. Futur. Energy Syst. Overv., p. 11, 2013.

[8] R. W. De Doncker, "Future DC Grid Technology for more Decentralized Power Production and Renewable Power Supplies," IEEE PEDG2012, 2012.

[9] A. Graillot, "Hybrid Micro Grids for rural electrification: Developing Appropriate Technology," presented at AIE Event, Maputo, 2009.

[10] A. Suzdalenko, "Research and Development of Control Means for Intelligent Household Electrical Grids," Ph.D. Thesis, Riga Technical University, 2013.

[11] "MED-Solar Training Course. Module 2. Microgrid Elements," Universitat Politecnica de Catalunya, p. 59.

[12] R. Villafáfila Robles, "Microgrids and emulation of distribution energy resources," p. 13.

[13] P. Karlsson, "DC Distributed Power Systems," Ph.D. Thesis, Lund University, 2002.

[14] D. Deaconu, A. Chirila, M. Albu and L. Toma, "Studies on a LV DC network," in 2007 European Conference on Power Electronics and Applications, 2007, pp. 1-7. https://doi.org/10.1109/EPE.2007.4417634

[15] A. Sannino, G. Postiglione and M. H. J. Bollen, "Feasibility of a DC network for commercial facilities," IEEE Trans. Ind. Appl., vol. 39, no. 5, pp. 1499-1507, 2003. https://doi.org/10.1109/TIA.2003.816517

[16] D. J. Hammerstrom, "AC versus DC distribution systems-did we get it right?," in 2007 IEEE Power Eng. Soc. Gen. Meet. PES, Tampa, FL, pp. 1-5, 2007. https://doi.org/10.1109/PES.2007.386130

[17] A. Kwasinski, "Micro-grids architectures, stability and protections," 2012.

[18] S. Rolland and G. Glania, "Hybrid Mini-Grids for Rural Electrification: Lessons Learned", CA: Renewable Energy House, Brussels, 2011, 72 p.

[19] A. Senfelds, M. Vorobjovs, D. Meike and O. Bormanis, "Power Smoothing Approach within Industrial DC Microgrid with Supercapacitor Storage for Robotic Manufacturing Application," in 2015 IEEE Int. Conf. on Automation Science and Eng. (CASE), Gothenburg, 2015, vol. 1020, pp. 1333-1338 https://doi.org/10.1109/CoASE.2015.7294283

[20] National Renewable Energy Laboratory, "Power Purchase Agreement Checklist for State and Local Governments," Golden, Colorado, 2009.

[21] M. A. Maehlum, "What's the Difference Between Net Metering and Feed-In Tariffs?," Energy Informative, 2014. [Online]. Available: http://energyinformative.org/net-metering-feed-in-tariffs-difference
[22] G. Zaleskis and I. Rankis, "Problem of an Estimation of the Wind Generators Economic Efficiency in Latvia," in Proceedings of the 20th International Conference ELECTRONICS 2016, Palanga, Lithuania, 2016, pp. 16-21.

[23] E. H. Camm, M. R. Behnke, O. Bolado et al., "Characteristics of Wind Turbine Generators for Wind Power Plants," in 2009 IEEE Power \& Energy Society General Meeting, Calgary, AB, 2009, pp. 1-5. https://doi.org/10.1109/pes.2009.5275330

[24] P. Suskis, "DC/DC Voltage H-Bridge Converter with Fuzzy Logic Control for Autonomous Power Supply," in 54 Int. Scientific Conf. of Riga Technical University, Riga, Latvia, 2013.

[25] P. Suskis, A. Andreiciks, I. Steiks, O. Krievs and J. Kleperis, "Microgrid for one side wind-and-hydrogen powered generation," Latvian Journal of Physics and Technical Sciences, no. 1, pp. 12-20, 2014.

[26] I. Galkins and O. Tetervenoks, "Efficiency considerations for noninverting buck-boost converter operating with direct current control," in 2014 16th European Conf. on Power Electronics and Applicat., Lappeenranta, 2014, pp. 1-8. https://doi.org/10.1109/EPE.2014.6911032

[27] O. Tetervenoks and I. Galkins, "Considerations on practical implementation of control system for switch mode current regulator," in 2014 14th Biennial Baltic Electronic Conference (BEC), Tallinn, 2014, pp. 225-228. https://doi.org/10.1109/bec.2014.7320597

[28] D. Connolly, "A Review of Energy Storage Technologies for the Integration of Fluctuating Renewable Energy," University of Limerick, $2009,46 \mathrm{p}$.

[29] I. Steiks, "Ūdeṇraža enerḡêtiskās iekārtas spēka elektronikas pārveidotāju izstrāde." Promocijas darbs, Rīgas Tehniskā universitāte, Rīga, 2011, 146 p.

[30] G. Zaleskis, I. Steiks, A. Pumpurs and O. Krievs, "DC-AC Converter for Load Supply in Autonomous Wind-Hydrogen Power System" in 56th Int. Scientific Conf. on Power and Electrical Engineering of Riga Technical University (RTUCON), Riga, Latvia, 2015, pp. 169-173. https://doi.org/10.1109/RTUCON.2015.7343118

[31] HyPM ${ }^{\circledR}$ Fuel Cell Power Modules, Hydrogenics, advanced hydrogen solutions. [Online]. Available: www.hydrogenics.com.

[32] Hy PM XR8 Installation, Operation and Maintenance Manual, Revision 2, DOC. P/N:1035409-02, Hydrogenics, Aug. 2010.

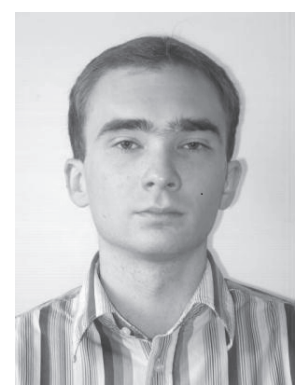

Genadijs Zaleskis, a Ph.D. Student, received the M.Sc. degree in electrical engineering from Riga Technical University in 2011.

In 2010-2011, he was a Laboratory Technician at the Institute of Industrial Electronics and Electrical Engineering of Riga Technical University. Since 2011, he is a Researcher at the Department of Industrial Electronics and Electrical Technologies of Riga Technical University. His main research fields are electrical technologies and automatic control. $\mathrm{He}$ is currently an Electrical Engineer at the Latvian Transmission System Operator "Augstsprieguma tīkls" Ltd.

Address: Institute of Industrial Electronics and Electrical Engineering, Riga Technical University, Āzenes iela 12/1, Riga, LV-1048, Latvia.

Phone: +37128380558

E-mail: genadijs.zaleskis@rtu.lv

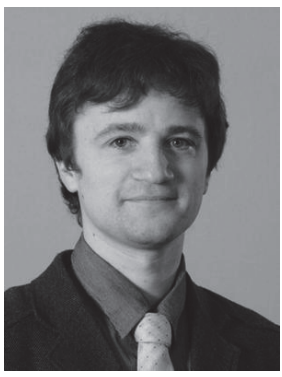

Ingars Steiks received the degrees of B.Sc., M.Sc., and Dr. sc. ing. in electrical engineering from Riga Technical University in 2004, 2006, and 2011 respectively. At present, I. Steiks is the Leading Researcher, and his main research fields include multilevel DC/AC converters and DC/DC converters for fuel cell applications.

Address: Institute of Industrial Electronics and Electrical Engineering, Riga Technical University, Āzenes iela 12/1, Riga, LV-1048, Latvia.

E-mail: ingars.steiks@rtu.lv 